\title{
Catholicism and the Study of Religion
}

\author{
Birgit Meyer
}

In this essay I would like to reflect on the conceptual implications of the proposition of the editors to take (the study of) Catholicism more seriously. However, I would like to make clear from the outset that I do not follow their call to take part in inaugurating the anthropology of Catholicism. First, as a scholar whose work predominantly focuses on Protestant missions and Pentecostal movements in Africa, I would not be equipped to play a role in this regard. Second, I am suspicious of the trend to launch ever more "anthropologies" of specific phenomena (a criticism I also have with regard to the anthropology of Christianity). While I concede that this may be a useful strategic move to orchestrate joint attention to a particular phenomenon, there is a danger of getting stuck. On my part, I rather want to think about Catholicism in relation to debates in the broader, multidisciplinary field of the study of religion, where the current material and bodily turn seeks to offer new directions that move beyond the long-dominant mentalistic emphasis on belief, content, and meaning that has been identified as the proverbial "Protestant bias" of modern understandings of religion. What difference does a focus on Catholicism make for how we position the study of religion conceptually at a moment when its "Protestant" underpinnings are subject to fundamental critique?

\section{CATHOLICISM, PROTESTANTISM, AND \\ THE MASTER NARRATIVE OF MODERNITY}

Current commonsense discourses about religion-certainly in the Netherlands, Germany, and the United States-often mobilize stereotypical views of Catholic and Protestant religiosities that are grounded in long-standing tensions between 
these two strands of Christianity as they arose in the aftermath of the Reformation and the rise of a post-Enlightenment modern order. While Catholicism is usually associated with the worship of saints and relics, ritual and sacraments, and a corporeal religiosity, Protestantism-and especially Calvinism-is held to be centered on Bible reading and a search for abstract meaning, inducing a mentalistic religiosity. Depending on the attitude of the beholder, these contrasts may be valued positively or negatively. Their use is, of course, problematic because it maintains long-standing prejudices and promotes an essentializing dualism that ties each of these two Christian traditions to a distinct, hierarchized type of religiosity. While actual theological and other differences between Catholicism and Protestantism-each, in turn, standing for a highly diverse tradition-certainly should not be brushed over, it would be mistaken to view them through the lens of such decontextualized, crude oppositions as those mentioned above.

The reason why I invoke these clichés is that their use points to a fundamental underlying issue: the complex relation between mind and body, between the spiritual and the material, between thinking and sensing, and between cognition and carnality in post-Reformation Protestant and Catholic Christianity and modernity at large. The mobilization of these dualisms in talking about Protestants and Catholics reveals much about tensions in current understandings of and approaches to modern Christianity and religion in general. The neat, simple idea of the superiority of the left side of these dualisms over the right side cannot be maintained in the light of everyday religious practice. Rather, these dualisms could be seen as the poles of a continuum that includes Protestant and Catholic religiosities. In this context it is intriguing to note that Protestant and Catholic are often employed as adjectives-usually tongue-in-cheek-that are severed from the particular Christian tradition they evoke (see Coleman, this volume). While the former stands for a sober, inward-oriented religiosity of the mind, the latter refers to exuberant rituals, triggering the body and the senses, and a rich material culture-an outwardoriented religiosity of the body. Placed in a temporalizing framework that regards Protestantism as the vanguard of modernity, the qualification of certain aspects of Catholic religious practice as "Protestant" acknowledges that Catholics are, as it were, catching up (even though there may "still" be significant differences between the enlightened clergy that sought to modernize Catholicism after the Second Vatican Council and ordinary, conservative believers). Conversely, though more rarely, Protestants may be qualified as displaying "Catholic" features. I find the latter qualification more intriguing because it challenges the typically modernist temporal scheme according to which Protestantism is profiled as the modern religion par excellence that breaks with the Catholic past. This suggests cracks in the familiar image of Protestantism as instigating a religious subjectivity that privileges mind above body, duty above desire, ratio above passion-the model of modern personhood. 
The scholarly version of this image was famously articulated by Max Weber in The Protestant Ethic and the Spirit of Capitalism. In his scenario of the rise of modern capitalism, the Reformation initiated a fundamental break between medieval Catholicism and modern Protestantism - epitomized by Calvinism and other Puritan movements, though to his dismay Lutheranism still was close to Catholicismthat eventually yielded a disenchanted society. For Weber, Catholic religiosity was characterized by the use of magical means-involving rituals, objects, body techniques, sacraments-in the pursuit of salvation that were authorized by the church and formed the basis of its power. ${ }^{2}$ In his thinking, medieval Catholicism was based on superstition and thus stood in fundamental contrast to the rational outlook emerging in consequence of the Calvinist doctrine of predestination that robbed believers of the possibility to employ such means to influence God. ${ }^{3}$ This introduced a new, rational relation between piety and worldly behavior (placement of one's conduct under the adage "Time is money" constant introspection, and methodological self-control) that eventually yielded the end of religion in a thoroughly rationalized society that became an iron cage.

From the outset, Weber's analysis, including his take on Catholicism, was contested. Apart from a number of remarks made in passing about Jesuits and Jansenists, Weber did not pay systematic attention to developments within postReformation Catholicism, such as the Council of Trent, the Counter-Reformation, and the baroque. By and large, he took Catholicism to be a less developed religion that had essentially not changed since the Middle Ages. Here it is not my intention to discuss how far his stance toward Catholicism was correct (in fact, he reproduced clichéd views as they were held in the German liberal Protestant milieu in the aftermath of the Kulturkampf) and how far his general thesis, which he refined and defended vigorously against a stream of criticisms until his death in 1920, can be maintained on empirical grounds. ${ }^{4}$ The point is that Weber's thesis about the prominent role of Calvinist Protestantism as a harbinger of modern capitalism proved to be powerful in shaping social and cultural thought at large and the sociology of religion in particular. He articulated a dominant "master narrative" about modernity as rational, disenchanted, and ultimately secular, ${ }^{5}$ and a view of Calvinist Protestantism as having transcended the importance attributed to practices, objects, the body, and sensations that had characterized medieval Catholicism. In short, the Calvinism of the "Protestant ethic" epitomized the rise of a dematerialized religiosity in an ever more materialistic world, ${ }^{6}$ and modernity was profiled as a "secular form of Protestantism." Catholicism, and all it was made to stand for, featured in this master narrative as Protestantism's Other and as a (to many, alas resilient and progress-impeding) matter of the past-a typical instance of what Johannes Fabian called "denial of co-evalness."

As pointed out by the German cultural sociologist Andreas Reckwitz, in the aftermath of Weber (and other towering figures, including Durkheim, Parsons, 
and Habermas) mainstream social and cultural theory approached modern society as being disenchanted and rational, as if the initially Protestant spirit of capitalism had de facto unleashed a broader process of sobering up (in German Ernüchterung) that allowed scholars to neglect the body, emotions, space, and objects as relevant topics of social and cultural analysis. ${ }^{9}$ Since the 1980 , this stance has been questioned ever more loudly and explicitly with the rise of postmodernism, which critiqued the claimed rationality and progressive orientation of the modernist project. This fueled the development of new epistemologies, theories, and concepts that move beyond the so far dominant approach to modern society in terms of abstract normative and symbolic orders. Various "turns" called attention to gender, the body and the senses, objects, space, emotions, and pictures, so as to affirm the importance of the material and concrete that had long and unduly been denied. Bruno Latour's statement "We have never been modern" aptly captured the growing realization of a cleavage between what modernity was presumed to be (as a project or master narrative) and what it actually came down to in everyday practice..$^{10}$ In this context, he identified the concept of the "fetish" as the prime symptom of a modern insistence on a clear dualism of persons and things that was ultimately impossible to be maintained in practice. Coining the notion of the "factish" - a mix of "fact" and "fetish" - and pointing out that "we help to fabricate the beings in which we believe," Latour went against the Protestant grain of modernity that was employed by Protestants to dismiss both Catholicism and non-Western religions as a superstitious worship of idols. ${ }^{11}$

Similarly, in their groundbreaking book Re-forming the Body the British sociologists Philip Mellor and Chris Shilling stress the ambivalent Janus-face of modernity, which, in their view, is characterized by a constant "resurgence of the flesh" that cannot be "easily contained within the cognitive orders of modernity."12 Behind the official face that privileges the mind above the body and the passions, the other face (building upon Schopenhauer and Nietzsche) reasserts the importance of the body, passions, and the senses. If the former is grounded in the Protestant Reformation with its typical ascetic and mind-oriented subjectivity, the latter is grounded in the Catholic Counter-Reformation that unleashed the baroque with its "voluptuous corporeality" and "seduction of the senses." ${ }^{13}$ They examine the differences and tensions between the re-formation of the body (understood as an actual, not merely metaphorical, corporeal process) and medieval Christianity, as well as between Protestantism and Catholicism in the modern period. Their admittedly schematic approach is lucid and provocative. While they accept the relevance of Weber's insights, they criticize sociology's exaggerated "focus on the legacy of Protestantism for the modern world" through which Catholicism is edited out of the master narrative of modernity. ${ }^{14}$ Mellor and Shilling point out that "the Reformation's rejection of carnal knowing was inherently problematic: there was always the danger that touch, taste, smell, sight and hearing could lead 
to the acquisition of heretical knowledge. Similarly, modernity's promotion of cognitive apprehension cannot eliminate the passion and sensations of bodies, however much it has tried to manage or repress them."15 They reject not only a reduction of modernity to a secular version of Protestantism but also a limited view of the latter in line with the ideal type (suggesting, in fact, that "Protestantism has never been Protestant"). Their analysis spotlights how bringing Catholicismand thus the body, images, sensations, emotions, passions, and ritual practicesinto the picture makes a crucial difference. Doing so derails familiar ways of narrating modernity that, as Mellor and Shilling point out, rely not only on an exaggerated Protestant bias but also on a biased Protestantism.

Above all, their work serves as a powerful reminder for scholars in the social and cultural sciences to take into account the importance of post-Reformation Catholicism and the baroque with its typical aesthetics of persuasion for contemporary modernity. ${ }^{16}$ They spotlight the rise of a new expression of human corporality that "can be associated with the emergence of a 'baroque modern' form of embodiment: a form marked by a sensualisation of experience, partly analogous to that evident in the Counter-Reformation baroque cultures, which develops hand in hand with an extension of certain aspects of the Protestant modern body."17 Indeed, the "lens of the baroque" is highly suitable for understanding the endurance of Catholicism as "a theological-political form" (as in the cult of the Virgin of Guadalupe; see Norget, this volume), and it throws into relief broader debates about the importance of the role of the senses, emotions, and experiences in binding people into current politico-aesthetic formations. ${ }^{18}$

\section{A TURNING POINT: FROM CRITIQUING PROTESTANT BIAS TO APPRAISING CATHOLIC RELIGIOSITY}

Of course, the overall critique deployed in mainstream social and cultural thought in analyzing modernity, as well as the various "turns" to the material and concrete, had parallels and repercussions in the study of religion. As Talal Asad argued powerfully, the modern study of religion is indebted to the legacy of post-Enlightenment Protestantism as framed within the master narrative of modernity. ${ }^{19}$ This implied that scholarly concepts and approaches employed to analyze religious practices and ideas all over the world echoed Protestant suspicions with regard to Catholic religiosity, emphasizing instead a logocentric concern with the Word of God (through the Bible, preaching, reading, prayer) or gods. Synthesizing Protestant logocentrism with German idealism and phenomenological subjectivism gave rise to, as Manuel Vásquez puts it, "a somatophobic [and I would add: icono-, object- and practice-phobic] Religionswissenschaft whose seductive power still holds sway today." ${ }^{20}$ Over the past twenty years, scholars have problematized the more or less unreflected projection onto other religions of arguably Protestant 
viewpoints that were mistaken for universal ones. The possibility of a universally applicable definition of religion was questioned, and a search for alternative approaches that take at face value the importance of the material and concrete is in full swing.

The critical concern to uncover the genealogy of the modern category of religion by pointing out its Protestant roots has great merits, but it also comes with its own intrinsic limitations. One problem I see is that the Protestant bias may easily be taken for real, rather than as an ideal type that reflects a particular theological and scholarly understanding. This yields a problematic affirmation of a caricature of Protestantism that is far removed from actual Protestant practice and lived religiosity. Indeed, "We should . . . be careful not to cast Protestantism as the villain in modern Christianity's denigration of the body and the external world." ${ }^{21}$ Detailed ethnographic and historical works, partly conducted within the anthropology of Christianity, have uncovered aspects and dimensions of Protestant practice in Europe, America and the global South that do not conform to stereotypical views of this strand of Christianity as basically being centered on Bible reading and a search for abstract meaning, inducing a mentalistic religiosity. ${ }^{22}$ This became even more obvious in the frontier zones of Western outreach where Protestant and Catholic missions confronted what they took as "heathendom" with theirsignificantly divergent-evangelizing projects. ${ }^{23}$

Second, the eagerness to spot and uncover a Protestant bias in the study of religion-over and over again - tends to sustain an appraisal of Protestantism as the cradle of modernity, at the very moment when critical scholarship unmasks and challenges this narrative, as pointed out above. The irony cannot be missed. If scholars in religious studies and the anthropology of religion have tended to mistakenly perceive concepts and assumptions as universal that were de facto rooted in a historically situated post-Enlightenment Protestant religiosity, scholars in the social and cultural sciences (whose main focus was the Western cultures and societies) have long tended to take more or less at face value the role of Calvinist Protestantism in the rise of modernity, understood in terms of rationalization and disenchantment. While uncovering the Protestant bias in the study of religion was a critical move that stated something hitherto ill-realized, the affirmation of the crucial role of Protestantism echoes a long-standing appraisal of the "Protestant Ethic" as the dominant scenario to account for the shape of modern society. In short, there is some degree of a mismatch between critical thought about the role of Protestantism in the study of religion, on the one hand, and in the social and cultural sciences, on the other. I think that it is time to move not only beyond critique of the "Protestant bias" but also beyond what is in my view its all too frequent invocation. ${ }^{24}$

So, if Protestantism cannot be reduced to how it was pictured in the Weberian scenario that shaped social and cultural theory, and if "we have never been modern" in a straightforward, progressive, rational sense, it is necessary for scholars to move 
further and open up the alternative archive of post-Reformation Catholicism. Of course, I do not propose to exchange the Protestant for a Catholic bias. The point is that the explicit role assigned to the body, the senses, objects, pictures, and rituals in the Catholic tradition can alert researchers to the broader relevance of materiality in religious practice at large and can prompt them to place Protestantism in a new light. ${ }^{25}$ To flesh out a material take on religion and society, Catholic religiosity-in past and present-warrants a closer look. One of the laudable achievements of this volume is that it showcases a host of old and new materials to do so.

\section{CATHOLIC MEDIATIONS-FRESH PERSPECTIVES}

As noted above, I am not an expert in the study of Catholicism and have no intention to delve into a separate anthropology devoted to this particular strand of Christianity. But I think that deeper knowledge about Catholic religiosity-regarding theological ideas and rituals as well as everyday practice - is important to allow for a shift in perspective so as to bring into the picture aspects that remain blind spots as long as religion is explored through a mentalistic (Protestant) lens. The background of this interest is that in my work on Protestant missions and Pentecostal movements in Ghana I encountered many instances that challenged facile assumptions about the nature of Protestantism as well as the idea that Pentecostals are the ultimate (post) modern exponents of Protestantism. This pertains both to the striving for a modern, far from sober and ascetic lifestyle (already in the early days of evangelizing and even more with the rise of Pentecostalism since the 1990s) and to the strong role of bodily sensations, the performance of ritual, and the value attributed to certain power objects (the Bible, the membership book) in religious practice. ${ }^{26}$ In short, I encountered the limits of what I took to be characteristic of Protestantism, and this prompted me to deploy an alternative, material approach that takes the body, sensations, objects, images, and rituals seriously as authorized harbingers that convey to believers a sense of divine presence, making God real.

Actually, my inclination to go for a material approach was grounded in a deep puzzlement about how to find a conceptual space to accommodate the explicit and deliberate human engagement in "doing" religion and effecting a genesis of divine presence that I encountered in my research among Protestants and Pentecostals. Gradually I realized that there was indeed a legacy of a Protestant-Calvinist inclination to privilege meaning, while making secondary the "outward" forms through which it was established and performed. From a Catholic perspective, the human ways of representing and approaching God would, of course, appear in another light. However, as far as I could see, there was no Catholic bias in place that could seriously compete with the Protestant one and that entailed alternative concepts and approaches in the study of religion that would suggest alternative takes on materiality and the human role in constructing religion. 
The current conceptualization of religion as a practice of mediation and of multiple media (understood in a broad sense) as intrinsic to that practice and as employed for "materializing the sacred" arose in this void. ${ }^{27}$ It is telling that Robert Orsi, as a scholar with long-standing expertise on Catholicism, played a lead role in this regard. Mediation, as is often remarked with a smile, is a "Catholic" thing. Indeed, Catholicism offers an explicit theology of mediation in which the body, objects, and practices are indispensable and are mobilized to bring about a sense of the "real presence of God," 28 as highlighted in the doctrine of the transubstantiation of the host and wine into the body of Christ, the veneration of saints, the prominent role of images in devotional practice, and so on. But an approach to religion as mediation is even more revealing if mediation-and thus the human input into the "fabrication of the beings in which we believe"-is not acknowledged or emphasized on the emic level. This makes it possible to uncover the semiotic ideologies through which the actual use of media is deemphasized, in favor of generating a sense of immediacy, in Protestant religious practice. ${ }^{29}$ As pointed out more extensively in other publications, I approach media that are authorized within specific religious traditions as "sensational forms" allowing believers to make the divine tangible in various shapes and to experience it as real. ${ }^{30}$ In the study of religion the medium of the book has traditionally received a great deal of attention (without being necessarily appraised as a medium, certainly within a Calvinist theological framework that stresses immediacy) and has produced an impressive philological and hermeneutical expertise. By contrast, the study of other media-for instance, images-has long been marginalized and thus has generated much less analytical know-how. To further develop the study of religion as a phenomenon that involves multiple media, a focus on Catholic images and attitudes to art can serve as a highly illuminating example.

The Reformation entailed a more or less violent media shift, from the central role of relics and images in (everyday) Catholic religiosity to the Reformers' emphasis on the Bible. In turn, the Counter-Reformation launched the baroque as a powerful statement against the iconoclastic stance of Calvinism. ${ }^{31}$ Communicating Catholic beliefs through the sensational display of art, the baroque style entailed a lavish aesthetics of persuasion that was spread across the world with, especially, Jesuit missions. This included the spread and reproduction of the most famous image of the Sacred Heart of Jesus painted by the Italian Pompeo Batoni (1760). Placed in an altar of the baroque Jesuit Church of Gesù in Rome, the image depicts the apparition of Jesus holding his bleeding heart to the French nun Margaret Mary Alacoque, who lived about one hundred years before the date of the painting. ${ }^{32}$ The image became the endlessly reproduced icon of the Catholic devotion to the Sacred Heart of Jesus. It has remained popular among Catholics up to today, as I also found through my research in Ghana. ${ }^{33}$ 
A stronger contrast between baroque art (and this image in particular) and Calvinism's sober style is barely imaginable. Protestant Calvinism rejected the representation of divinity in any form and dismissed the devotional use of images. ${ }^{34}$ This brought about the rise of a separate domain of art and aesthetics that was independent from the sphere of religion. As a consequence, art history and religious studies were worlds apart. With the rise of the pictorial or iconic turn in art history and visual studies, on the one hand, and an approach to images as religious media and an increased interest in the "icon" in the study of religion, on the other, new synergies have emerged since the 1990 o between these so far disconnected fields. ${ }^{35}$ For good reasons. Scholars in visual studies seek to come to grips with the apparent capacity of images to appear animated and enchanted and to think about how to account for their "power," life," or "agency." ${ }^{6}$ There is a remarkable recycling and reproduction, via ever new media, of iconographic traditions and pictorial genres from the Catholic past. ${ }^{37}$ And there is an apparent resilience and proliferation of visual regimes grounded in the Catholic baroque, at a time when northern Europe is caught up in a process of unchurching. Indeed, to invoke Mellor and Shilling once again, the "tension between cognition and carnality that shaped the post-Reformation era is at the heart of the advanced modern experience of the world: seductive images have returned in the modern information age, and it is even possible to talk of the emergence of a form of embodiment which is both 'baroque' and 'modern."' ${ }^{38}$ A deep understanding of these processes demands sustained collaboration between scholars in visual culture and religious studies, which in my view is beneficial to both sides. To gain such understanding, a focus on Catholic religiosity and its rich visual culture is an indispensable requirement.

Focusing on images as prominent religious media, I also want to make a more general point. As I pointed out, my motivation to look at Catholicism is not grounded in an interest in this brand of Christianity per se; rather, it stems from the idea that doing so offers a much-needed corrective. So, to take up the question posed in the beginning of this essay: What difference does a focus on Catholicism make for how we position the study of religion conceptually? Turning to Catholicism as an alternative archive allows for a critique of the Protestant legacy that shaped the master narrative of modernity as well as the study of religion across the world and offers fresh insights for conceptualizing and approaching religion from a material angle. Of course, I do not wish to affirm a stereotyped dualism that maps Protestantism and Catholicism on simple oppositions such as mentalistic and material. As I hope to have made clear, actual lived Protestant religiosity does not conform to such a view (and the same holds for Catholicism). The point is that paying attention to Catholic religiosity is helpful to further flesh out an approach to religion that acknowledges the role of the body, objects, and human practice in generating a sense of divine presence. This approach should ultimately transcend the mental-material distinction, as well as the spectrum of Christianity. 


\section{NOTES}

I would like to thank the editors for inviting me to write this essay, and Jojada Verrips and Bruno Reinhardt for stimulating comments on an earlier version.

1. Asad (1993).

2. Weber ([1905] 2001, 61). See also Otto $(2005,236-37)$.

3. Weber $([1905] 2001,71)$.

4. See H. Lehmann (2009, 107-15); Schluchter (2005, 68-72).

5. Van Rooden $(1996,203)$. See also Cox (2001).

6. Meyer (2010a, 743-50); Meyer and Houtman (2012, 9-13); see also Keane (2003, 411); Keane (2007).

7. As aptly put by Seidler, quoted in Mellor and Shilling $(1997,144)$.

8. Fabian (1983). The exclusivist mobilization of time remained central to modernist discourse up until today, as contemporary characterizations of Islam as "backward" show.

9. Reckwitz (2012). Their existence was, of course, not denied, but their analysis was regarded as relevant, not to sociology, but to fields other than sociology (e.g., emotions were relegated to psychology, understood as a science directed to the individual).

10. Latour (1993).

11. Latour $(2010,39)$.See also Keane (2007, 79-81); Meyer (2014).

12. Mellor and Shilling $(1997,156)$.

13. Mellor and Shilling $(1997,134-38)$.

14. Mellor and Shilling $(1997,8)$.

15. Mellor and Shilling $(1997,156)$.

16. See also Ndalianis (2004); van de Port (2013).

17. Mellor and Shilling $(1997,11)$.

18. Meyer (2009). See also Böhme (1995); Rancière (2006).

19. Asad (1993).

20. Vásquez $(2011,32)$.

21. Vásquez $(2011,32)$.

22. E.g., Klassen (2011); McDannell (1995); Verrips (2013).

23. E.g., Keane (2007); Meyer (1999).

24. This critique is also directed to myself; see Meyer (2014).

25. Engelke (2011, 221).

26. See Meyer (2014, 213-14); see also Meyer (1997, 311-37).

27. Orsi $(2012,147)$.

28. Butticci (2016). See also Butticci's fascinating website on Pentecostal aesthetics: www .pentecostalaesthetics.net.

29. Meyer $(2011,29)$.

30. Meyer (2006; 2011, 217-18). In this context I would like to note that Niklaus Largier's fascinating exposé of the bodily and sensorial practices of medieval mystics (this volume) and their deployment in romanticism strikes me as showing surprising similarities with contemporary Pentecostal religious practice and its specific sensational forms. This surprising recognition underlines the importance of spotting continuities, rather than mistaking the Reformation as a watershed that entailed a full break with medieval religiosity.

31. Belting (1990, 538-45); Schwebel (2002, 71-73).

32. Morgan (2012b, 90-111).

33. Napolitano (2007, 71-87). Cheap reproductions (made in China) are available throughout southern Ghana. Such posters are also popular among non-Catholics. While the image is employed as an icon that conveys to believers a sense of the presence of God and the power of Jesus, others reject it 
as an illicit material form that operates as an "idol" or "fetish." The uses and debates about this image illustrate the extent to which long-standing tensions between Protestant and Catholic stances to images-as idols or icons-have spread on a global scale and inform current attitudes to (religious) visual culture. See Meyer (2010b, 100-130); Woets (2016).

34. It would be mistaken to characterize Protestantism as iconophobic. Images played a role in Protestant religious practice up to the present. The Protestant spectrum is differentiated, and especially in Lutheran churches pictures are displayed and parts of the pre-Reformation Catholic heritage are maintained. Generally shared among Protestants are illustrations in Bibles and pictures of biblical scenes and Jesus. The crucial point concerns the theological rejection of images as harbingers of divine presence. In everyday practice, as David Morgan (1998) showed, images of Jesus may be at the center of popular Protestant devotional piety.

35. On the interest in religious studies concerning images as religious media, see, e.g., Pentcheva (2006, 631-55); Lührmann (2010, 56-78). On new connections between this approach and the iconic turn in art history, see Meyer (2015, 6-14).

36. See, e.g., Freedberg (1989); Gell (1998); W. Mitchell (2004).

37. Weigel (2015).

38. Mellor and Shilling $(1997,157)$. 